\title{
Shine \& Lal index as a predictor for early detection of $\beta$-thalassemia carriers in a limited resource area in Bandung, Indonesia
}

Ani Melani Maskoen ${ }^{1 *}\left(\mathbb{D}\right.$, Lelani Reniarti ${ }^{2}$, Edhyana Sahiratmadja ${ }^{3}$, Joice Sisca $^{4}$ and Sjarif Hidajat Effendi ${ }^{2}$

\begin{abstract}
s
Background: Thalassemia is the most common inherited disease in the world, involving a- or $\beta$-globin in red blood cells. Thalassemia cases rank fifth in the list of national catastrophic diseases in Indonesia; however, nationwide screening for thalassemia carriers is not yet mandatory. This study aimed to assess whether blood count metrics, such as the Shine \& Lal index (SLl; $\left.M \mathrm{MVV}^{*} \mathrm{MCV}^{*} \mathrm{MCH} / 100\right)$, might serve as a predictor to screen thalassemia carriers in a limited resource area where molecular methods are not readily available.

Methods: During a family gathering of thalassemia patients, family members (n196) underwent a complete blood count test. Those with MCV < $80 \mathrm{fL}$ and/or $\mathrm{MCH}<27 \mathrm{pg}$ and/or SLI $<1530$ were further examined for $\mathrm{Hb}$ analysis. Only samples with $\mathrm{HbA} 2$ fraction $>4 \%$ or with a peak in the $\mathrm{HbE}$ fraction were sequenced to confirm $\beta$-globin gene mutations.

Results: Of 196 family members, 117 (59.6\%) had low MCV and/or low MCH and/or low SLI. The HbE fraction (mean 24.06\% \pm 0.95 , range 22.4-26.5) was found in 27 (13.7\%) cases, and all had a mutation at codon (CD)26 (c.79G > A). The mean $\mathrm{HbA}_{2}$ fraction in these samples was 3.18\% 0.62 (range 2.6-3.8). For samples with $\mathrm{HbA2}>4 \%$ (n30; 15.3\%), all had mutations at IVS1nt5 (c.92 + 5 G > C; n28), CD8/9 (c.27_28insG; n1) and CD19 (c.59A > G; n1). The mean $\mathrm{HbA}_{2}$ fraction with a mutation at IVS1nt5 (c.92 + $5 \mathrm{G}>\mathrm{C}$ ) was $4.65 \% \pm 0.77$ (range 4.0-5.6). Interestingly, anaemia was only present in 25 and $57 \%$ of $\beta$-thalassemia carriers with mutations at CD26 (c.79G > A) and at IVS1nt5 (c.92 + 5 $\mathrm{G}>\mathrm{C}$ ), respectively.

Conclusions: The Shine \& Lal index is helpful in the early screening of $\beta$-thalassemia carriers, since this index confirms mutations at CD-26 (c.79G > A) and at IVS1nt5 (c.92 + 5 G > C), which are both common mutations in Bandung, Indonesia. Further DNA analysis is a topic of interest to map variants in globin genes and their distribution across populations.
\end{abstract}

Keywords: $\mathrm{HbA}_{2}, \mathrm{HbE}$, IVS1nt5, $\beta$-Thalassemia

\footnotetext{
*Correspondence: amelani@yahoo.com

${ }^{1}$ Department of Oral Biology, Faculty of Dentistry, Universitas Padjadjaran,

Bandung, Indonesia

Full list of author information is available at the end of the article
}

(c) The Author(s). 2019 Open Access This article is distributed under the terms of the Creative Commons Attribution 4.0 International License (http://creativecommons.org/licenses/by/4.0/), which permits unrestricted use, distribution, and reproduction in any medium, provided you give appropriate credit to the original author(s) and the source, provide a link to the Creative Commons license, and indicate if changes were made. The Creative Commons Public Domain Dedication waiver (http://creativecommons.org/publicdomain/zero/1.0/) applies to the data made available in this article, unless otherwise stated. 


\section{Background}

Thalassemia is an inherited disease caused by mutations in the $\alpha$ - or $\beta$-globin gene. The two $\alpha$ - and two $\beta$-globin chains form tetramers of globin, and together with haem and iron, they form the haemoglobin $(\mathrm{Hb})$ molecule of red blood cells in normal adults [1]. The $\alpha$-globin gene cluster is located on chromosome 16 (16p13.3), whereas the $\beta$-globin gene cluster is located on chromosome 11 (11p15.5). Mutation or deletion in the $\alpha$ - or $\beta$-globin gene may result in a reduction or an absence of globin production, leading to a low $\mathrm{Hb}$ concentration. Mutations in the $\beta$-globin gene (HBB, NM_000518) are common in populations around the Mediterranean area, the Middle East, Central Asia and the Far East, as well as in Southeast Asia, including Indonesia [2]. Homozygous individuals carrying mutations in the $\beta$-globin gene are designated as $\beta$-thalassemia major patients, and this patient requires lifelong regular blood transfusion [3]. The heterozygous individual carrying a $\beta$-globin gene mutation is known as a thalassemia carrier or trait. This thalassemia carrier passes the mutation to their offspring in an autosomal recessive manner [3]. Since $\beta$-thalassemia major cases are increasing, early detection of heterozygous individuals carrying $\beta$-globin gene mutations is a point of interest.

In Indonesia, the prevalence of anaemia is high. Anaemia in this region is often described as anaemia due to iron deficiency, especially in children and young women [4]. Although anaemia has been declining over the years, it remains a moderate public health problem. Because Indonesia is located along the 'thalassemia belt' area, low $\mathrm{Hb}$ may reflect other red blood disorders, such as haemoglobinopathies [2]. However, screening of thalassemia carriers in Indonesia is only sporadically conducted.

A complete blood count test, including $\mathrm{Hb}$, mean corpuscular volume (MCV), and mean corpuscular haemoglobin $(\mathrm{MCH})$, is a routine blood examination in clinical laboratories. Several haematological indices are introduced to categorize microcytic anaemia into an iron deficiency anaemia (IDA) or a carrier state of $\beta$ thalassemia, such as the Mentzer index (MCV/RBC), Srivastava index $(\mathrm{MCH} / \mathrm{RBC})$, Shine \& Lal index (MCV $\left.[2]{ }^{*} \mathrm{MCH} / 100\right)$ and many other indices [5]. However, the sensitivity and specificity of these indices vary across regions [6]. Although haematological indices can be used to diagnose presumptive $\beta$-thalassemia carriers, a recent development shows that $\mathrm{Hb}$ analysis, including fractions of $\mathrm{HbA} 2, \mathrm{HbA}$, or $\mathrm{HbF}$, may confirm or exclude the $\beta$ thalassemia carrier state. Moreover, new technology can detect the form of the $\mathrm{HbE}$ fraction [7], thus recommending $\mathrm{Hb}$ analysis for further confirmation results $[8,9]$. Moreover, because more than 200 different thalassaemic mutations have been reported in the $\beta$-globin gene, it is necessary to confirm the diagnosis and to map the mutation spectrum among populations. In a limited resource area such as Indonesia, $\mathrm{Hb}$ analysis and molecular examination are expensive. Therefore, this study aimed to explore whether the Shine \& Lal index might have a beneficial factor as a predictor to detect a carrier state of thalassemia carriers in the general population, especially in areas where molecular examination is not readily available. Furthermore, common mutations among $\beta$-thalassemia carriers were described.

\section{Methods}

\section{Participants and sample collection}

First degree family members, including father and/or mother and/or siblings, were invited to participate in the screening of thalassemia carrier status during a family gathering of thalassemia patients in Dr. Hasan Sadikin General Hospital, Bandung, Indonesia. In this family gathering, a mini seminar was held and involved professional speakers, including a paediatrician, clinical pathologist, and the Indonesian Thalassemia Foundation. Written consent was obtained from all adult participants. A form letter containing a carrier screening agreement for children younger than 16 years old was signed by their parents.

Venous blood was collected in a $3 \mathrm{~mL}$ EDTA tube, and the complete blood count was examined, including $\mathrm{Hb}$, $\mathrm{MCV}$ and $\mathrm{MCH}$. Anaemia was defined according to WHO criteria: $\mathrm{Hb}<13 \mathrm{~g} / \mathrm{dL}$ and $<12 \mathrm{~g} / \mathrm{dL}$ for males and females, respectively. Only those who had MCV $<80 \mathrm{fL}$ and/or $\mathrm{MCH}<27 \mathrm{pg}$ and/or Shine \& Lal index $<1530$ were further subjected to $\mathrm{Hb}$ analysis using capillary electrophoresis (Minicap Sebia, France). This machine could separate the $\mathrm{HbE}$ fraction from HbA2; therefore, the sample with the $\mathrm{HbE}$ value was further sequenced (Fig. 1a). The other samples were grouped based on HbA2 fraction values of normal (2.2-3.2\%), borderline (3.3-3.9\%) and high (>4\%) as shown in Fig. 1b, c, and d. Only samples with high HbA2 (>4\%) (Fig. 1d) were further examined for common $\beta$-globin gene mutations due to limited financial sources.

The protocol of the study was approved by the Ethics Committee of the Faculty of Medicine, Universitas Padjadjaran, with ethical clearance no. 966/UN6.C.10/ PN/2017.

\section{Detection of mutations in the $\beta$-globin gene}

DNA was isolated from EDTA venous blood, and the $\beta$ globin gene (HBB gene; NM_000518) was amplified using the forward and reverse primer sets as follows: forward primer TLF62028 (ComC) 5'ACCTCACCCTGTGGAGCCAC3', and reverse primer TLR62320 5'CTATTGG TCTCCTTAAACCTGTCTTGTAACCTTGCTA3’. Polymerase chain reaction was carried out on a thermal cycler (GeneAmp ${ }^{\circ}$ PCR system 9700, Applied Biosystems) using 


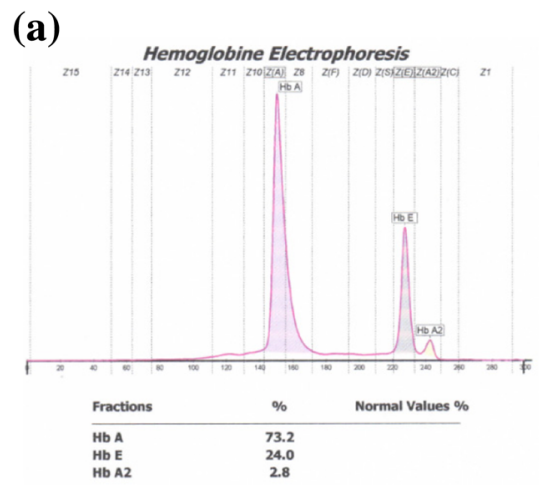

(c)

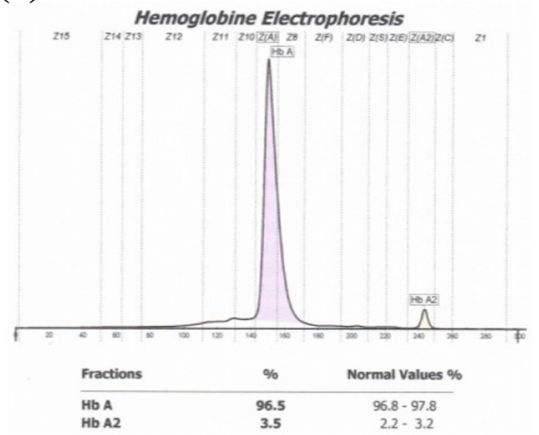

(b)

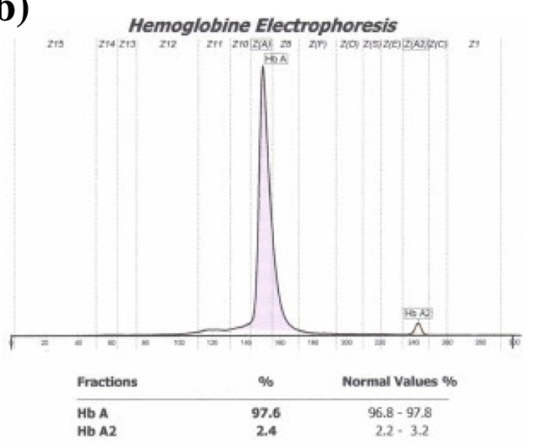

(d)

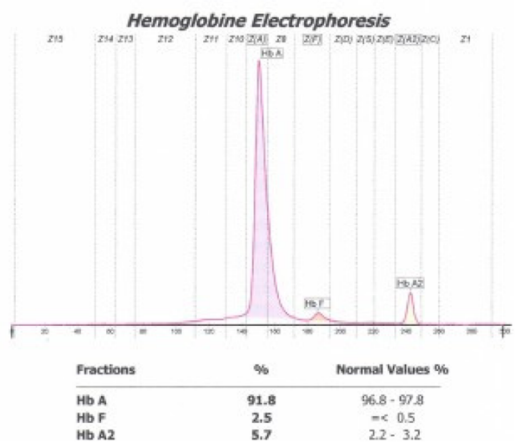

Fig. 1 Peaks of various $\mathrm{Hb}$ fractions ( $\mathrm{HbA}, \mathrm{HbA} 2, \mathrm{HbF}$, and $\mathrm{HbE}$ ) by capillary electrophoresis. $\mathrm{HbE}$ is clearly shown next to $\mathrm{HbA2}$ (a), and all samples have mutations at c.79G > A (CD26). HbA2 is normal (2.2-3.2\%) and borderline (3.2-3.9\%), as shown in (b) and (c), respectively. HbA2 is high (> 4\%) (d), and most samples have mutations at C92 + 5G > C (IVS1nt5)

the following conditions: initial denaturation at $95 \mathrm{C}$ for 5 min, followed by 35 cycles at $95 \mathrm{C}$ for $30 \mathrm{~s}, 68 \mathrm{C}$ for $30 \mathrm{~s}$, $72 \mathrm{C}$ for $1 \mathrm{~min}$, and a final extension at $72 \mathrm{C}$ for $5 \mathrm{~min}$. The PCR band was then visualized in $2 \%$ agarose gel, running at $50 \mathrm{~V}$ for $30 \mathrm{~min}$ before further sequencing (First Base, Malaysia). The $\mathrm{Hb}$ fractions ( $\mathrm{HbA} 2, \mathrm{HbA}$ and $\mathrm{HbE}$ ) were compared between groups of common $\beta$-globin mutations (c.79G > A vs. c92 + 5G > C) as previously described [10].

\section{Statistical analyses}

Anaemia prevalence was compared between groups of common $\beta$-globin mutations (c.79G > A vs. c92 + 5G > $\mathrm{C})$ using the $X$-square test. The values of the $\mathrm{Hb}$ fractions ( $\mathrm{HbA} 2, \mathrm{HbA}$ and $\mathrm{Hb} \mathrm{E}$ ) were checked to determine whether the data were normally distributed, and the mean values were compared between groups of common $\beta$-globin mutations using a t-test. Analysis was performed by SPSS v.22 for Windows, licensed for Universitas Padjadjaran.

\section{Results}

Of 196 family members participating in a complete blood count examination, 117 had low MCV $(<80 \mathrm{fL})$ and/or low $\mathrm{MCH}(<27 \mathrm{pg})$ and/or low Shine \& Lal index $(<1530)$. The Hb electrophoresis results showed a high peak HbE level in 27 (13.7\%) participants (mean 24.06\% \pm 0.95; range 22.4-26.5) (Table 1). Further sequencing analysis of the samples with high $\mathrm{HbE}$ levels revealed a mutation at codon (CD) 26 (c.79G > A) (Fig. 2b).

The other samples with low MCV and/or low $\mathrm{MCH}$ and/or low Shine \& Lal index and no $\mathrm{HbE}$ peak had various HbA2 levels, ranging from normal (n40), borderline (n20), and high (n30) levels of HbA2. All samples with high HbA2 levels (> 4\%) had mutations at IVS1nt5 (c.92 + 5G > C; n28) (Fig. 2a), CD 8-9 (c27_28insG; n1) and CD 19 (c.59A > G; n1; known as HbMalay).

There was a significant difference $(p<0.001)$ in the HbA2 level between the mutation at CD26 (c.79G > A) and at IVS1nt5 (c.92+5G>C), with mean values of $3.18 \% \pm 0.62$ (range $2.6-3.8$ ) and $4.65 \% \pm 0.77$ (range 4.0 $5.6)$, respectively (Table 1 ). Interestingly, anaemia was only found in 25 and $57 \%$ of the mutations at CD26 (c.79G > A) and at IVS1nt5 (c.92 + 5 G > C), respectively.

\section{Discussion}

Thalassemia cases are becoming a global health problem due to population migration [11]. This disease is increasing in Indonesia and listed as the fifth in the national catastrophic disease, making thalassemia an emerging national burden. However, the screening of thalassemia 
Table 1 Distribution of anaemia and Hb fraction analysis in association with $\beta$-globin gene mutations at C.79G > A (CD-26) and at C92 + 5G > C (IVS1nt5) among carrier thalassemia individuals from Bandung, Indonesia

\begin{tabular}{|c|c|c|c|c|c|c|c|}
\hline \multirow[b]{3}{*}{ Anaemic status } & \multicolumn{6}{|c|}{$\beta$-globin mutation } & \multirow[b]{2}{*}{$P$ value } \\
\hline & \multicolumn{2}{|l|}{ c.79G > A } & \multirow[t]{2}{*}{$(C D-26)$} & \multicolumn{2}{|c|}{$c 92+5 G>C$} & \multirow[t]{2}{*}{ (IVS1nt5) } & \\
\hline & $n$ & (\%) & & $n$ & (\%) & & \\
\hline Anaemic & 7 & $(25.9)$ & & 16 & $(57.1)$ & & $0.019^{\#}$ \\
\hline Not anaemic & 20 & $(74.1)$ & & 12 & $(42.9)$ & & \\
\hline $\mathrm{Hb}$ fractions & Mean & $\pm s d$ & (min-max) & Mean & $\pm s d$ & (min-max) & \\
\hline $\mathrm{HbE}$ & $24.06 \%$ & \pm 0.95 & $(22.4-26.5)$ & - & & & \\
\hline $\mathrm{Hb} \mathrm{A} 2$ & $3.18 \%$ & \pm 0.62 & $(2.6-3.8)^{a}$ & $4.65 \%$ & \pm 0.77 & $(4.0-5.6)$ & $<0.001^{\# \#}$ \\
\hline $\mathrm{Hb} \mathrm{A}$ & $72.51 \%$ & \pm 0.18 & $(69.7-74.1)$ & $95.23 \%$ & \pm 0.08 & $(94.4-96.2)$ & $<0.001^{\# \#}$ \\
\hline
\end{tabular}

Note: ${ }^{\mathrm{a}} \mathrm{HbA} 2$ is normal (2.2-3.2\%) and borderline (3.3-3.9\%)

Statistical significance is set at $p<0.05 ;{ }^{\#} \mathrm{X}$-square test or ${ }^{\# \#}$ t-test (data normally distributed)

carriers in Indonesia is not a mandatory yet. In some countries, screening of thalassemia carrier status is encouraged in basic health care services [11]. Moreover, cascade screening among family members has proven to be cost effective after identifying thalassemia carrier individuals [12]. Therefore, we have initiated screening of first degree family members of thalassemia patients for their carrier status.

Various formulas using a complete blood count have been developed to detect $\beta$-thalassemia carriers in areas where the prevalence of thalassemia major is high; however, specificity and sensitivity vary across regions [13]. Our study has shown that cell counter-based parameters such as the Shine \& Lal index may serve as a good predictor to detect haemoglobinopathies at the earliest stage. Even though we only had eight parameters of complete blood count examination in our study, the Shine \& Lal index $<1530$ could predict all $\beta$-thalassemia carriers with mutations at $\mathrm{c} 92+5 \mathrm{G}>\mathrm{C}$ and c.79G $>$ A. Both mutations are regarded as the most prevalent mutations among populations in West Java, Indonesia [10]. Interestingly, anaemia is only prevalent in 57.1 and $25.9 \%$ of $\beta$-thalassemia carrier IVS1nt5 (c92 + 5G > C) and $\mathrm{HbE}(\mathrm{c} .79 \mathrm{G}>\mathrm{A})$ variants, respectively, indicating that most individuals have normal $\mathrm{Hb}$ or are non- anaemic, though they have low SLI. SLI has thus been proven to be a valid discriminating index to distinguish between IDA and $\beta$-thalassemia [14], as also shown in our previous study [15].

Furthermore, HbA2 analysis plays an important role in distinguishing IDA and $\beta$-thalassemia carriers [16], for example, anaemia with $\mathrm{HbA} 2>4 \%$ indicates a $\beta$ thalassemia carrier with a mutation at IVS1nt5 (c92+ $5 \mathrm{G}>\mathrm{C}$ ). The increase in HbA2 becomes an important parameter for thalassemia carrier identification. However, samples with low SLI and normal or borderline HbA2 levels may suggest an IDA or possible $\alpha$-thalassemia carrier with deletional or non-deletional $\alpha$-globin gene defects, and this needs to be further analysed by molecular analysis [17]. The machine used in our study showed a high peak of $\mathrm{HbE}$, which is clearly separated from $\mathrm{HbA} 2$ (Fig. 1a), and all confirmed a mutation at c.79G $>$ A, while some machines showed a very high value of $\mathrm{HbA} 2$, indicating the $\mathrm{HbE}$ variant. Our study showed that the $\mathrm{HbA} 2$ fraction value for the $\mathrm{HbE}$ variant is normal or borderline, in concordance with the study by Mais et al. (2009) [18].

Mutations at IVS1nt5 (c.92G>C) and at CD 26 (c.79G > A) are common in Indonesia; however, both mutations might have different phenotypes [19]; therefore, molecular analysis is necessary. Since the DNA

\section{CA I I S IA GT G GTRAG CC}

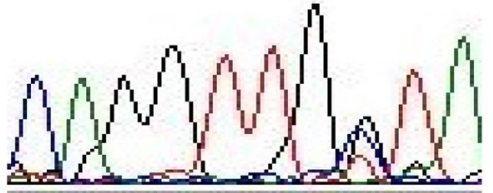

(a)

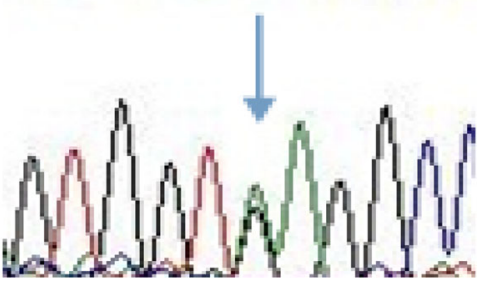

(b)

Fig. 2 Sequences from individuals with mutations in the $\beta$-globin gene (HBB, NM_000518) at C92 + 5G > C (IVS1nt5) (a) or at c.79G > A (CD-26) (b) 
analysis is limited and expensive, screening strategies for thalassemia and $\mathrm{HbE}$ in rural communities in our region may be directed to previously published guidelines $[20,21]$. Some researchers suggest a simple way to detect mutations using techniques such as the multiplex amplification refractory mutation system (ARMS) PCR or PCR-RFLP [22] rather than sequencing or the most recent diagnostic-based array [23].

This study had several limitations; the lack of family pedigrees to establish genotype/phenotype segregation is a major issue in this study. A better database of family members' registries has recently been established. Another limitation of this study is that iron profile examination is lacking. Furthermore, respondents with a low Shine \& Lal index who have normal or borderline $\mathrm{HbA} 2$ were not further examined for possible other $\alpha$-globin gene mutations; therefore, DNA analysis must be performed since co-inheritance of IDA and $\beta$-thalassemia and $\alpha$ - and $\beta$-thalassemia might occur even in rare cases $[24,25]$.

\section{Conclusion}

In a limited resource area such as Indonesia, the Shine \& Lal index may have great value in predicting $\beta$ thalassemia carrier status in the general population. Wherever it is available, further screening of iron and HbA2 profiles is necessary; by all means, molecular examination is the most necessary examination to confirm the point mutation or deletion in $\alpha$ - or $\beta$-thalassemia carrier detection, which is needed to map the mutation spectrum among populations.

\section{Acknowledgements}

We are grateful to the Indonesian Thalassemia Foundation (YTI) and the Foundation of Parents and Thalassemia Patients (POPTI) in Bandung, West Java, for organizing the family gathering event.

\section{Authors' contributions}

AMM and DSH conceived and designed the study: LR was responsible for thalassemia patient data; AMM, LR, ES, JS, and DSH presented during data collection; JS performed the study in the laboratory; JS and ES conducted data analyses; JS and AMM wrote the first draft, and it reviewed by ES. All authors read and approved the final manuscript.

\section{Funding}

This study is funded by The Academic Leadership Grant (ALG) Universitas Padjadjaran 2017, given to DSH as principal investigator.

Universitas Padjadjaran as the funding body has no role in the design of the study and collection, analysis, and interpretation of data and in writing the manuscript.

\section{Availability of data and materials}

Datasets used and/or analysed during the current study are available on reasonable request.

Please email e.sahiratmadja@unpad.ac.id, cc. corresponding author amelani@yahoo.com.

\section{Ethics approval and consent to participate}

Ethical clearance was granted by the Ethics Committee of the Faculty of Medicine, Universitas Padjadjaran (http://kepk.fk.unpad.ac.id/no.966/UN6.C.10/ PN/2017) no. 966/UN6.C.10/PN/2017.
Written consent was obtained from all adult participants. A form letter containing the carrier screening agreement for children younger than 16 years old was signed by their parents.

\section{Consent for publication}

Not applicable

\section{Competing interests}

The authors declare that they have no competing interests.

\section{Author details}

${ }^{1}$ Department of Oral Biology, Faculty of Dentistry, Universitas Padjadjaran, Bandung, Indonesia. ${ }^{2}$ Department of Pediatrics, Dr. Hasan Sadikin General Hospital/Faculty of Medicine, Universitas Padjadjaran, Bandung, Indonesia. ${ }^{3}$ Department of Biomedical Sciences, Faculty of Medicine, Universitas Padjadjaran, Bandung, Indonesia. ${ }^{4}$ Biotechnology Master Program,

Postgraduate School, Universitas Padjadjaran, Bandung, Indonesia.

Received: 5 October 2018 Accepted: 29 July 2019

Published online: 09 August 2019

\section{References}

1. Weatherall DJ. The inherited diseases of hemoglobin are an emerging global health burden. Blood. 2010;115(22):4331-6. https://doi.org/10.1182/ blood-2010-01-251348.

2. Fucharoen S, Winichagoon P. Haemoglobinopathies in southeast Asia. Indian J Med Res. 2011;134:498-506.

3. Cao A, Kan YW. The prevention of thalassemia. Cold Spring Harb Perspect Med. 2013;3(2):a011775. https://doi.org/10.1101/cshperspect.a011775.

4. Barkley JS, Kendrick KL, Codling K, Muslimatun S, Pachón H. Anaemia prevalence over time in Indonesia: estimates from the 1997, 2000, and 2008 Indonesia family life surveys. Asia Pac J Clin Nutr. 2015;24(3):452-5.

5. Okan V, Cigiloglu A, Cifci S, Yilmaz M, Pehlivan M. Red cell indices and functions differentiating patients with the beta-thalassaemia trait from those with iron deficiency anaemia. J Int Med Res. 2009;37(1):25-30.

6. Hoffmann JJ, Urrechaga E, Aguirre U. Discriminant indices for distinguishing thalassemia and iron deficiency in patients with microcytic anemia: a metaanalysis. Clin Chem Lab Med. 2015;53(12):1883-94.

7. Allaudin $\mathrm{H}_{1}$ Yussof $\mathrm{M}$, Khirofdin $\mathrm{A}$, Ali M. $\mathrm{HbA}_{2}$ levels in normal, $\beta$-thalassemia and hemoglobin $\mathrm{E}$ carriers by capillary electrophoresis. Malaysian J Pathol. 2012;34(2):161-4

8. Stephens AD, Angastiniotis M, Baysal E, Chan V, Fucharoen S, Giordano PC, Hoyer JD, Mosca A, Wild B, International Council for the Standardisation of Haematology (ICSH). ICSH recommendations for the measurement of haemoglobin A2. Int J Lab Hematol. 2012;34:1):1-13. https://doi.org/1 0.1111/j.1751-553X.2011.01368.x.

9. Giambona A, Passarello C, Renda D, Maggio A. The significance of the hemoglobin A(2) value in screening for hemoglobinopathies. Clin Biochem. 2009:42(18):1786-96

10. Maskoen AM, Rahayu NS, Reniarti L, Susanah S, Laksono B, Fauziah PN, Zada A Hidayat DS. Mutation spectrum of $\beta$-globin gene in thalassemia patients at Hasan Sadikin Hospital - West Java Indonesia. Cell Mol Biol (Noisy-le-grand) 2017;63(12):22-4. https://doi.org/10.14715/cmb/2017.63.12.6.

11. Modell B, Darlison M. Global epidemiology of haemoglobin disorders and derived service indicators. Bull World Health Organ. 2008;86(6):480-7.

12. Gorakshakar AC, Colah RB. Cascade screening for $\beta$-thalassemia: a practical approach for identifying and counseling carriers in India. Indian J Com Med. 2009:34(4):354-6.

13. Rathod DA, Kaur A, Patel V, Patel K, Kabrawala R, Patel V, Patel M, Shah P. Usefulness of cell counter-based parameters and formulas in detection of beta-thalassemia trait in areas of high prevalence. Am J Clin Pathol. 2007; 128(4):585-9.

14. Huang TC, Wu YY, Chen YG, Lai SW, Wu SC, Ye RH, Lu CS, Chen JH. Discrimination index of microcytic anemia in young soldiers: a single institutional analysis. PLoS One. 2015;10(2):e0114061. https://doi.org/1 0.1371/journal.pone.0114061.

15. Susanti Al, Sahiratmadja E, Winarno G, Sugianli AK, Susanto H, Panigoro R. Low Hemoglobin among Pregnant Women in Midwives Practice of Primary Health Care, Jatinangor, Indonesia: Iron Deficiency Anemia or $\beta$-Thalassemia Trait? Anemia. 2017;2017:6935648. 
16. Panyasai S, Fucharoen G, Fucharoen S. Known and new hemoglobin A2 variants in Thailand and implication for $\beta$-thalassemia screening. Clin Chim Acta. 2015;438:226-30.

17. Paglietti ME, Satta S, Sollaino MC, Barella S, Ventrella A, Desogus MF, Demartis FR, Manunza L, Origa R. The Problem of Borderline Hemoglobin A2 Levels in the Screening for $\beta$-Thalassemia Carriers in Sardinia. Acta Haematol. 2016;135(4):193-9.

18. Mais DD, Gulbranson RD, Keren DF. The range of hemoglobin $A(2)$ in hemoglobin E heterozygotes as determined by capillary electrophoresis. Am J Clin Pathol. 2009;132(1):34-8.

19. Eshghi P, Rashidi A, Zadeh-Vakili A, Miri-Moghadam E. Hematological phenotype of the IVS-I-5 ( $\mathrm{G}>\mathrm{C}$ ) beta-thalassemia mutation and assessment of Iran's national screening criteria. Hemoglobin. 2008;32(5):440-5. https://doi.org/10.1080/0363026 0802341778

20. Harahap A, Megawati D, Nainggolan IM, Swastika M, Setianingsih I. The role of complete blood count in the diagnosis of hemoglobin $\mathrm{E}$ in Pseudo high level of hemoglobin $A_{2}$. Hematology. 2015. https://doi.org/10.13055/ ojhmt_6_1_5.150516.

21. Fucharoen G, Sanchaisuriya K, Sae-ung N, Dangwibul S, Fucharoen S. A simplified screening strategy for thalassaemia and haemoglobin $\mathrm{E}$ in rural communities in south-east Asia. Bull World Health Organ. 2004;82(5):364-72.

22. Hassan S, Ahmad R, Zakaria Z, Zulkafli Z, Abdullah WZ. Detection of $\beta$ globin gene mutations among $\beta$-thalassaemia carriers and patients in Malaysia: application of multiplex amplification refractory mutation systempolymerase chain reaction. Malays J Med Sci. 2013;20(1):13-20.

23. Sabath DE, Bender MA, Sankaran VG, Vamos E, Kentsis A, Yi HS, Greisman HA. Characterization of Deletions of the HBA and HBB Loci by Array Comparative Genomic Hybridization. J Mol Diagn. 2016;18(1):92-9.

24. Rahman M, Khan L. Co-inheritance of $\alpha$ and $\beta$ thalassemia in a Bangladesh family. BSMMUJ. 2017;10:123-5.

25. Rahim F, Kaikhaei B, Zandian K, Hoseini A. Co-inheritance of alpha-and betathalassemia in Khuzestan Province, Iran. Hematology. 2008;13(1):59-64.

\section{Publisher's Note}

Springer Nature remains neutral with regard to jurisdictional claims in published maps and institutional affiliations.

Ready to submit your research? Choose BMC and benefit from:

- fast, convenient online submission

- thorough peer review by experienced researchers in your field

- rapid publication on acceptance

- support for research data, including large and complex data types

- gold Open Access which fosters wider collaboration and increased citations

- maximum visibility for your research: over $100 \mathrm{M}$ website views per year

At $\mathrm{BMC}$, research is always in progress.

Learn more biomedcentral.com/submissions 